
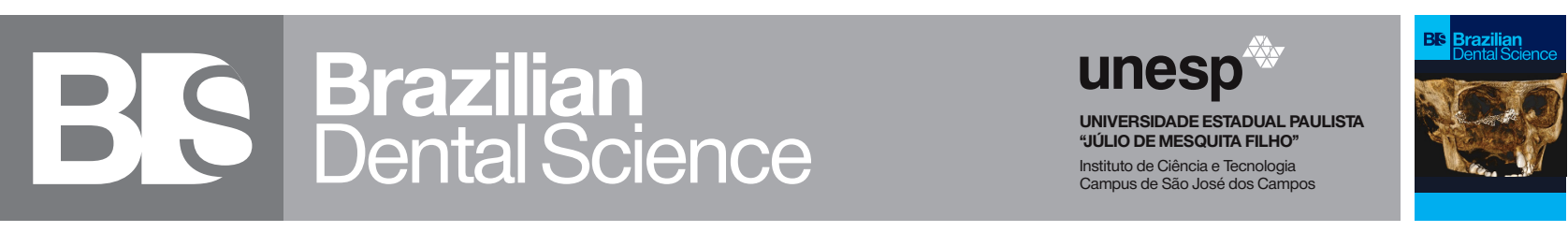

\title{
Antimicrobial efficacy of a new tri-antibiotic combination against resistant endodontic pathogens: an in-vitro study
}

Eficácia antimicrobiana de uma nova combinação tripla de antibióticos contra patógenos endodônticos resistentes: um estudo in vitro

\author{
Prasanna T. DAHAKE ${ }^{1}$, Sudhindra M. BALIGA ${ }^{2}$ \\ 1 - Pharmacology and Pedodontics - DMIMS (Deemed to be University) - Pharmacology and Pedodontics - (Interdisciplinary Sciences) - \\ Sawangi (M), Wardha - Maharashtra - India. \\ 2 - DMIMS (Deemed to be University) - Sharad Pawar Dental College and Hospital - Department of Pedodontics and Preventive Dentistry, \\ Sawangi (M), Wardha,Maharashtra - India.
}

\begin{abstract}
Background: Removal of all the pathogenic bacteria from the root canal system is of prime importance for the success of endodontic therapy. Objective: The study aimed to determine the antimicrobial efficacy of three antibiotics and their new combination against selected endodontic pathogens. Methods: In this invitro study, we used bacterial strains associated with the refractory endodontic condition and determined MIC and MBC of Clindamycin (C), Metronidazole (M), Doxycycline (D) as well as their combination CMD. We cultured Candida Albicans, Pseudomonas Aeruginosa, Escherichia Coli, Enterococcus Faecalis, Streptococcus Mutans, Bacillus Subtilis subsp. spizizenii, Actinomyces Actinomycetemcomitans on selective culture media. We analyzed the data using paired ' $\mathrm{t}$ ' test, one-way ANOVA, and Tuckey's HSD post hoc test. Results: Clindamycin inhibited the growth of C. Albicans (90\%) and S. Mutans (90\%) significantly and P. Aeruginosa, E. Coli, E. Faecalis, B. Subtilis, and A. Actinomycetemcomitans were resistant to it. Metronidazole did not inhibit any of the bacteria. Doxycycline inhibited C. Albicans (90\%), P. Aeruginosa (90\%), and S. Mutans (90\%) significantly while E. Coli, E. Faecalis, B. Subtilis, and A. Actinomycetemcomitans were resistant to it. The combination of CMD inhibited all the microbes significantly. However, at bactericidal concentrations of CMD, E. Faecalis $(p=0.024)$, B. Subtilis $(\mathrm{p}=0.021)$ and A. Actinomycetemcomitans ( $\mathrm{p}=0.041)$ were eliminated significantly, while C. Albicans $(p=0.164)$, P. Aeruginosa $(p=0.489)$, E. Coli $(p=0.106)$ and S. Mutans $(p=0.121)$ showed resistance. Conclusion: Combination CMD can be used against resistant endodontic pathogens to achieve predictable endodontic results.
\end{abstract}

\section{KEYWORDS}

Antimicrobial agents; Clindamycin; Doxycycline; Metronidazole; Root canal therapy.

\section{RESUMO}

Antecedentes: A remoção de todas as bactérias patogênicas do sistema de canais radiculares é de primordial importância para o sucesso da terapia endodôntica. Objetivo: O estudo teve como objetivo determinar a eficácia antimicrobiana de três antibióticos e sua nova combinação contra patógenos endodônticos selecionados. Métodos: Neste estudo in vitro, foram utilizadas cepas bacterianas associadas à condição endodôntica refratária e determinado CIM e MBC de Clindamicina (C), Metronidazol (M), Doxiciclina (D), bem como sua combinação de DMC. Cultivamos Candida Albicans, Pseudomonas Aeruginosa, Escherichia Coli, Enterococcus Faecalis, Streptococcus Mutans, Bacillus Subtilis subsp. spizizenii, Actinomyces Actinomycetemcomitans em meios de cultura seletivos. Analisamos os dados usando o teste ' $\mathrm{t}$ ' emparelhado, ANOVA unidirecional e o teste post hoc HSD de Tuckey. Resultados: A clindamicina inibiu significativamente o crescimento de C. Albicans (90\%) e S. Mutans (90\%) e P. Aeruginosa, E. Coli, E. Coli, E. Faecalis, B. Subtilis e A. Actinomycetemcomitans eram resistentes a ele. O metronidazol não inibiu nenhuma das bactérias. A doxiciclina inibiu significativamente C. Albicans (90\%), P. Aeruginosa (90\%) e S. Mutans (90\%), enquanto E. Coli, E. Faecalis, B. Subtilis e A. Actinomycetemcomitans eram resistentes a ela. A combinação de CMD inibiu significativamente todos os micróbios. Entretanto, em concentrações bactericidas de CMD, E. Faecalis $(p=0,024)$, B. Subtilis ( $\mathrm{p}=0,021)$ e A. Actinomycetemcomitans ( $\mathrm{p}=$ 0,041) foram eliminados significativamente, enquanto $C$. Albicans ( $p=0,164)$, P. Aeruginosa $(p=0,489)$, E. Coli ( $p$ $=0,106)$ e S. Mutans $(\mathrm{p}=0,121)$ apresentaram resistência. Conclusão: O CMD combinado pode ser usado contra patógenos endodônticos resistentes para obter resultados endodônticos previsíveis.

\section{PALAVRAS-CHAVE}

Agentes antimicrobianos; Clindamicina; Doxiciclina; Metronidazol; Terapia de canal radicular. 


\section{INTRODUCTION}

$\mathrm{M}$ icroorganisms reside passively in the oral cavity and stay harmless till the patient's immunity is compromised, or become active due to mutations or expression of few virulence traits enhancing pathogenicity [1] like biofilm formation [2]. These biofilms as plaque, enhance synergistic associations among virulent pathogenic microorganisms [3]. It is responsible for dental caries, periodontal as well as other oral diseases, which are practically challenging for dental professionals to treat [4].

The microbiological invasions into occult endodontic spaces are difficult to eliminate through routine biomechanical preparation [5], irrespective of the irrigation systems, making treatment prognosis uncertain [6]. Elimination of endopathogens with biofilm is the aim of endodontic therapy. Various agents like phenols, aldehydes, corticosteroids, calcium hydroxide, chlorhexidine, and antibiotics [7] have been tried with variable outcomes. Calcium hydroxide loses its efficacy easily due to dentinal protein buffering; low diffusibility through dense microbial biofilms [8]. Phenolic compounds demonstrated cytotoxicity, mutagenicity, and teratogenicity [9]. Chlorhexidine and aldehydes become ineffective upon contact with organic debris or non-ionic surfactants [10]. Corticosteroids alter inflammatory cell function, delaying wound healing, hence also not advisable in nonvital teeth [11]. Antibiotics, when used alone fall prey to multi-drug resistant microorganisms losing their antimicrobial activity later [12]. The emergence of such strains has prompted the search of a reliable and biologically safe multi-antimicrobial combination to target such microorganisms [13].

Intracanal application of multi-antimicrobial preparations reduces the chances of systemic toxicity and achieves almost complete microbial elimination at very low concentrations [14]. The topical multi-antimicrobial preparations have been used against endopathogens with variable success $[15,16]$. But, the exact doses of agents were not determined, and also the concerns regarding systemic adverse effects secondary to prolonged exposure of ciprofloxacin and minocycline were also not addressed [17].

Till now, no previous studies have explored the combination of clindamycin, metronidazole, and doxycycline as a possible intracanal medicament against multiple endopathogens. Thus, the present experimental study was planned with the hypothesis that efficacy of combination CMD is better than individual antimicrobial agents; clindamycin $(\mathrm{C})$, metronidazole $(\mathrm{M})$, doxycycline (D), against selected endodontic microbial strains.

\section{MATERIAL AND METHODS}

The present study was carried out at the department of pedodontics in association with the department of microbiology after gaining clearance from the Institutional Ethical Committee, letter no. DMIMS(DU)/IEC/2015-16/1744. The antimicrobial activity of different antimicrobial agents was tested against standard strains of microorganisms.

\section{Antimicrobial agents used for the experiment}

Here the analytical grade, commercially available antimicrobial agents were used. Clindamycin HCL (C) and doxycycline HCL (D) were provided by HiMedia Labs Pvt Ltd, Mumbai, India, while metronidazole (M) was provided by MP Biomedicals, LLC, France.

\section{Bacterial strains used}

The bacterial strains used were ATCC (American Type Culture Collection) type and provided by Microbiologics, USA, through HiMedia Labs Pvt Ltd, Mumbai, India. Based on the clinical correlation associated with the refractory endodontic conditions, it was decided to use following bacterial strains namely, Candida Albicans (ATCC 10231), Pseudomonas Aeruginosa (ATCC 27853), Escherichia Coli (ATCC 25922), Enterococcus Faecalis (ATCC 35550), Streptococcus Mutans (ATCC 25175), Bacillus Subtilis subsp. spizizenii (ATCC 6633), Aggregatibacter Actinomycetemcomitans (ATCC 29523).

\section{Preparation of microbial suspension}

After opening the bacterial vials, the lyophilized bacterial cells were revived by adding with sterile brain heart infusion broth (BHI) at room temperature under the strict aseptic condition in laminar flow biological safety cabinet (BioClean Air Devices, Chennai, TN, India), to avoid contamination from environmental microbes. After revival, these bacterial broths were used as direct colony suspensions, to prepare secondary bacterial 
aliquots by mixing into BHI broth. The turbidity of each secondary aliquot was adjusted visually to $0.5 \mathrm{McF}$ arland standards and confirmed for all the isolates, by spectrophotometer $\left(\right.$ Orion $^{\mathrm{TM}}$, AquaMate 8000 UV-Vis, Thermo-Fisher Scientific, US) at an optical density (OD600:0.6-0.7), comprising $1 \times 10^{7}$ colony forming units (CFU)/ml[18].

\section{Preparation of stock solutions of antimicrobial agents}

The stock solutions of all the antimicrobial agents (C, M, D) were prepared as per the procedures mentioned by Miles et al.,[19]. While preparing the stock solution, one-milligram powder of antimicrobial agent was mixed into 10 $\mathrm{ml}$ sterile distilled water and vortexed (SPINWIN Centrifuge, Korea) to obtain their homogeneous solution at a concentration of $1000 \mu \mathrm{g} / \mathrm{ml}$. All the stock solutions were kept at 4 to $8^{\circ} \mathrm{C}$ in light-proof containers to prevent desiccation and oxidation of the active ingredients until further use [20].

Determination of minimum inhibitory concentration (MIC) of antimicrobial agents through double dilution method

In this study, the MIC of each antimicrobial agent was calculated through the serial dilution method through the use of BHI broth. From every stock solution, $1 \mathrm{ml}$ of antimicrobial solution was diluted in a two-fold manner from $1000 \mu \mathrm{g} /$ $\mathrm{ml}$ to $0.2 \mu \mathrm{g} / \mathrm{ml}$ respectively. The last tube with sterile BHI broth without any test agent was kept as a negative control. For determining MIC through this method, all the steps were followed as per Clinical and Laboratory Standard Institute (CLSI) guidelines [21]. $5 \mu \mathrm{l}$ of secondary bacterial aliquot was added to each MIC tubes followed by vortexing (SPINWIN Centrifuge, Korea), to get a homogenous suspension. All the tubes were then incubated in a phase-change microbiological incubator (Adarsh International, Haryana, India), through aerobic and anaerobic modes $37^{\circ} \mathrm{C}$ for 24$48 \mathrm{~h}$ to achieve good bacterial growth. The MIC of each antimicrobial agent was determined by visual inspection as the absence of turbidity in the broth and confirmed through spectrophotometer at an optical density (OD600:0.6-0.7) [20]. The lowest concentration of antimicrobial agent showing no bacterial growth was considered as MIC of the agent for that particular bacteria. All the procedures were repeated in triplicates to minimize errors [18].

\section{Determination of minimum bactericidal concentration (MBC) using colony-forming unit (CFU) method}

To calculate the MBC for antimicrobial agents, $5 \mu \mathrm{L}$ of the incubated broth from MIC tubes was streaked onto the culture plates containing nutrient agar and incubated for $48 \mathrm{~h}$ at $37^{\circ} \mathrm{C}$ aerobically and anaerobically. The lowest concentration of the antimicrobial agent showing no appearance of CFU on media was considered as the MBC for that particular agent and bacteria respectively [18].

\section{Statistical analysis}

All the data for each sample and test was entered into an excel spreadsheet and subjected to statistical analysis using IBM SPSS Statistics for Windows, Version 22.0 (IBM Corp., Armonk, N.Y., USA) using descriptive statistics. The values of MIC and MBC were calculated as mean and standard deviation. To determine intra-group variance, paired ' $\mathrm{t}$ ' test was used. While to determine intergroup variance, One-way ANOVA followed by Tukey's post hoc HSD test with a confidence level of $95 \%$ ( $\mathrm{P}<0.05)$ was used.

\section{RESULTS}

There were statistically significant differences present in the mean MIC of various drugs for different bacteria. One-way ANOVA signified the overall comparison. The antimicrobial susceptibilities of bacterial species were investigated by determining MIC and MBC.

Table I shows the inhibitory concentration and sensitivity of all the antimicrobial agents against selected bacteria. The sensitivity of C. Albicans and S. Mutans was 90\% against clindamycin, doxycycline as well as combination CMD except for metronidazole (20\% and 30\% respectively). P. Aeruginosa exhibited 90\% sensitivity to doxycycline and 80\% to CMD. E. Coli and E. Faecalis demonstrated sensitivity against combination CMD 90\% and 70\% respectively but resistance against individual agents. The sensitivity of B. Subtilis was found to be $80 \%$ while that of A. Actinomycetemcomitans was 90\%. But both were resistant to individual agents. 
Table I - Minimum inhibitory concentration (MIC) of Clindamycin, Metronidazole, Doxycycline, and combination (CMD) against selected endodontic bacteria.

\begin{tabular}{|cccccccc|}
\hline Groups & C.Albicans & P.Aeruginosa & E. Coli & E. Faecalis & S. Mutans & B. Subtilis & $\begin{array}{c}\text { A.Actinomycetem- } \\
\text { comitans }\end{array}$ \\
\hline Clindamycin & $90 \%$ & $20 \%$ & $20 \%$ & $20 \%$ & $90 \%$ & $10 \%$ & $30 \%$ \\
\hline Metronidazole & $20 \%$ & $20 \%$ & $10 \%$ & $10 \%$ & $30 \%$ & $10 \%$ & $30 \%$ \\
\hline Doxycycline & $90 \%$ & $90 \%$ & $10 \%$ & $30 \%$ & $90 \%$ & $30 \%$ & $40 \%$ \\
\hline (CMD) & $90 \%$ & $80 \%$ & $90 \%$ & $70 \%$ & $90 \%$ & $80 \%$ & $90 \%$ \\
\hline Chi-square test & 18.433 & 17.143 & 20.339 & 9.459 & 14.4 & 14.929 & 9.925 \\
\hline p value & $p<0.001^{\star *}$ & $p=0.001^{*}$ & $p<0.001^{* *}$ & $p=0.02^{*}$ & $p=0.002^{*}$ & $p=0.002^{*}$ & $p=0.019^{*}$ \\
\hline
\end{tabular}

Sensitivity in percentage (\%), ${ }^{* *}$-Highly significant $(p<0.001),{ }^{*}$-Significant $(p<0.05)$, NS-Not Significant $(p>0.05)$.

In this study, the MBC was calculated as the minimum concentration of the antimicrobial agent to kill $99.9 \%$ viable micro-organisms relative to starting inoculum or the negative control after the incubation. Table II shows the MBC of test agents against selected bacteria. The highest resistance to clindamycin was demonstrated by A. Actinomycetemcomitans (152 $\pm 4.32 \mathrm{mg}$ ), and B. subtilis (109 $\pm 5.3 \mathrm{mg}$ ), while E. Faecalis $(87.17 \pm 6.7 \mathrm{mg})$ and E. Coli $(69.67 \pm 5.5 \mathrm{mg})$ were moderately resistant. C. Albicans $(26 \pm 4.68 \mathrm{mg})$ displayed weak resistance, whereas. S. Mutans (13.83 \pm 3.8 $\mathrm{mg})$ P. Aeruginosa $(11.33 \pm 2.76 \mathrm{mg})$ exhibited the least resistance to it. Against metronidazole, the highest resistance was exhibited by C. Albicans $(94.83 \pm 3.85 \mathrm{mg})$; B. Subtilis $(91 \pm$ $2.1 \mathrm{mg}$ ) and A. Actinomycetemcomitans (83 \pm $1.32 \mathrm{mg}$ ). Moderate resistance was exhibited by E. Faecalis $(63.16 \pm 5.4 \mathrm{mg})$ and E. Coli $(55.33$ $\pm 3.7 \mathrm{mg}$ ). While S. Mutans (36.83 $\pm 2 \mathrm{mg}$ ) and P. Aeruginosa $(16.16 \pm 2.46 \mathrm{mg})$ showed the least resistance. Against doxycycline, B. Subtilis $(52.66 \pm 3.4 \mathrm{mg})$, C. Albicans (38.33 \pm 1.08 $\mathrm{mg}$ ), E. Coli (30.16 $\pm 1 \mathrm{mg}$ ), P. Aeruginosa (30 $\pm 0.0 \mathrm{mg}$ ) and E. Faecalis $(24.33 \pm 3.9 \mathrm{mg})$ showed moderate resistance. While the least resistance was shown by S. Mutans (3.83 \pm $2.39 \mathrm{mg}$ ), and A. Actinomycetemcomitans (1.07 $\pm 0.47 \mathrm{mg}$ ). Against combination CMD, all the bacteria demonstrated weak resistance against it. The bacteria usually responsible for refractory endodontic lesions viz. E. Faecalis $(15.3 \pm 2.31$ $\mathrm{mg})$, P. Aeruginosa (14.59 $\pm 2.57 \mathrm{mg})$, E. Coli $(8.83 \pm 2.94 \mathrm{mg})$, A. Actinomycetemcomitans $(8.03 \pm 3.79 \mathrm{mg})$, C. Albicans $(7.3 \pm 1.04 \mathrm{mg})$, B. Subtilis $(7.03 \pm 1.02 \mathrm{mg})$, and S. Mutans (1 $\pm 0.05 \mathrm{mg}$ ), were weakly resistant against the new combination.

Table II - Minimum inhibitory concentration (MIC) of Clindamycin, Metronidazole, Doxycycline, and combination (CMD) against selected endodontic bacteria.

\begin{tabular}{|cccccccc} 
Groups & C.Albicans & P.Aeruginosa & E. Coli & E. Faecalis & S. Mutans & B.Subtilis & $\begin{array}{c}\text { A.Actinomycetem- } \\
\text { comitans }\end{array}$ \\
& Mean \pm SD & Mean \pm SD & Mean \pm SD & Mean \pm SD & Mean \pm SD & Mean \pm SD & Mean \pm SD \\
\hline NC & $250 \pm 00$ & $250 \pm 00$ & $250 \pm 00$ & $250 \pm 00$ & $250 \pm 00$ & $250 \pm 00$ & $250 \pm 00$ \\
\hline Clindamycin & $26.0 \pm 4.68$ & $11.33 \pm 2.76$ & $69.66 \pm 5.5$ & $87.17 \pm 6.7$ & $13.83 \pm 3.8$ & $109.0 \pm 5.3$ & $152.0 \pm 4.32$ \\
\hline Metronidazole & $94.83 \pm 3.85$ & $16.16 \pm 2.46$ & $55.33 \pm 3.7$ & $63.16 \pm 5.4$ & $36.83 \pm 2$ & $91.0 \pm 2.1$ & $83.0 \pm 1.32$ \\
\hline Doxycycline & $38.33 \pm 1.08$ & $30.0 \pm 0.0$ & $30.16 \pm 1$ & $24.33 \pm 3.9$ & $3.83 \pm 2.39$ & $52.66 \pm 3.4$ & $1.07 \pm 0.47$ \\
\hline CMD & $7.3 \pm 1.04$ & $14.59 \pm 2.57$ & $8.83 \pm 2.94$ & $15.3 \pm 2.31$ & $1.0 \pm 0.05$ & $7.03 \pm 1$ & $8.03 \pm 3.79$ \\
\hline p value & $p=0.164 \mathrm{NS}$ & $p=0.489 \mathrm{NS}$ & $\mathrm{p}=0.106 \mathrm{NS}$ & $\mathrm{p}=0.024^{*}$ & $\mathrm{p}=0.121 \mathrm{NS}$ & $\mathrm{p}=0.021^{\star}$ & $p=0.041$ \\
\hline
\end{tabular}

NC - Negative Control, ${ }^{* *}$-Highly significant $(p<0.001)$, ${ }^{*}$-Significant $(p<0.05)$, NS-Not Significant $(p>0.05)$. 


\section{DISCUSSION}

Pulp has limited vasculature and lymphatic drainage, hence exhibit a diversified response to biological, physical, or chemical irritants. Immature teeth with highly vascular pulp may sustain irritants for a considerable time, which may not be true for mature teeth [5]. Damaged pulp with its degradation products provides a favorable environment for polymicrobial colonization and growth inside pulp space. Few of them can sustain high variations in $\mathrm{pH}$, redox potential, O2, and nutrient requirements [5,22].

Endodontic pathogens are acquired from the oral cavity, carious tooth, anachoresis, or pre-contaminated inadequately sterilized dentinal tubules. They can be either facultative or obligate, aerobes, and anaerobes [23]. The Gram-negative anaerobic bacteria are responsible for characteristic clinicopathologic features of endodontic diseases [24]. The abovementioned micro-organisms were included in the present study, owing to their high association with endodontic diseases and resistance to elimination through biomechanical preparation. The inclusion of diversified microbial species also helps to assess the possible antibiotic resistance attributed to the exchange of different genes in form of intrinsic, acquired, or tolerance type of resistance [25].

These endodontic pathogens form biofilms among tortuous inaccessible spaces as well as among obturating material and dentinal walls [23]. Bacillus Subtilis exhibit virulence through spore and biofilm formation around facilitating their attachment and survival against antimicrobial agents [24]. E. Faecalis otherwise isolated infrequently from untreated canals can establish at a higher number due to inadequate disinfection leading to persistent periapical infections. The presence of a polysaccharide capsule makes it resistant to a wide range of temperature, $\mathrm{pH}$, and antimicrobial agents [26]. A. Actinomycetemcomitans become part of the endo-periodontal lesion by entering through lateral and apical accessory canals establishing in apical and periapical areas [27]. P. Aeruginosa also exhibits enhanced virulence and resistance to antimicrobial agents in endodontic infections secondary to biofilm formation [28]. S. Mutans are derived from dentinal caries, also participate in primary endodontic infection [29]. All these bacteria show different characteristics as a single entity, but completely diversified behaviors altogether in mixed microbial ecology. They symbiose propagation, growth, and survival for each other, through either extracellular protein, glycoproteins, or mucopolysaccharide encouraging bacterial attachments and preventing exposures to antimicrobial agents $[26,29]$.

The elimination of all the endodontic pathogens along with their byproducts is the key factor for predictable endodontic therapy [29]. But previous experimental studies have demonstrated the presence of microbial remnants in endodontic spaces even after thorough chemo-mechanical preparation and irrigation [30], leading to therapeutic failures. Intracanal medicaments help to eradicate residual microbial remnants, particularly in pulpless teeth, teeth with apical periodontitis, pulp necrosis, and refractory endodontic cases, reducing dependence on adjunctive systemic antimicrobial therapy [31].

Though calcium hydroxide and chlorhexidine are considered as the intracanal medicament of choice, they have been found inefficient to eliminate many microbial species [7]. The previous report had shown weaker responses of calcium hydroxide and chlorhexidine to eliminate few endopathogens compared to triple antibiotic paste [32]. Likewise, few studies have documented better effectivity of anti-microbial agents like clindamycin [33], metronidazole [34] and doxycycline [35] compared to them.With increasing evidence of microbial resistance to nonantimicrobial intracanal medicaments [7], an attempt was made in this experiment to develop a multi-antimicrobial combination with precise minimum microbicidal concentration.

A combination of clindamycin, metronidazole, and doxycycline was proposed in 
the present study, as all the agents demonstrate microbiostatic and microbicidal properties. At therapeutic dose clindamycin exhibits bactericidal, whereas at subinhibitory dose, opsonization and phagocytosis enhancer for microbial cells [36]. Metronidazole eradicates protozoa as well as $\mathrm{Gm}+$ ve and $\mathrm{Gm}$-ve anaerobic bacteria due to microbial DNA and enzymatic degradation [37]. However, altered qualitative or quantitative doses make it susceptible to bacterial resistance, preferably facultative anaerobes. It shows promising results as part of a multidrug regimen against endodontic and odontogenic infections [37]. Doxycycline also has a wide spectrum of antimicrobial activity against many endopathogens [38], and with other additives, acts as dentin hardener as well as smear layer and pulp solvent [39].It also exhibits intrinsic anti-inflammatory and anticollagenolytic activity through reduced matrix metalloproteinase (MMP) expression [40].

Among all the individual agents tested in this study, clindamycin showed the highest sensitivity against all the bacterial isolates, which are in agreement with previous studies $[38,39]$. Metronidazole exhibited the least sensitivity against all bacteria, similar to the results of LeCorn et al., [41]. Doxycycline also demonstrated comparable sensitivity results, which are similar to results obtained by Chan and Chan [42]. Considering the mechanism of action, MIC and MBC of individual antimicrobial agent, it was decided to mix clindamycin, metronidazole, and doxycycline, at a ratio of 5:5:1, respectively to formulate a newer combination CMD. This combination presented good results the in form of inhibitory and bactericidal values, indicating high elimination potential and less resistance development during the therapeutic regimen. Such an outcome might be attributed to multilocation microbial cell damage including cell wall, microsomal apparatus, ribosome, mitochondria, RNA, and protein synthesis cycle. The possibility of microbial cells surviving this multilevel damage is relatively less [36].
The application of such combination as an intracanal medicament and at close vicinity to periradicular tissues may help to accomplish sterilization of endodontic spaces efficiently, which in turn might decrease therapeutic failures also. For antimicrobial agents, concentrationdependent activity, like in CMD, would be better for such application than time-dependent modality probably as the contact time of the agents would be limited. Thus, the hypothesis of combining clindamycin, doxycycline, and metronidazole exhibiting better efficacy than individual agents to eliminate selected endodontic pathogens, was accepted.

\section{LIMITATIONS}

The present study has the following limitations like:

1) It was an in-vitro study, and can't replicate clinical conditions;

2) The individual agents were tested against the combination and didn't include other nonantibiotic agents like calcium hydroxide or chlorohexidine;

3) Only a few bacterial strains were included due to financial limitations.

\section{CONCLUSION}

In this study, the newly formulated combination CMD was found effective against all the selected microbial species. Based on the results obtained, the combination CMD can be recommended against resistant endodontic pathogens to achieve predictable endodontic results. However, for more reproducible results and stouter inferences, further clinical studies are recommended.

Conflict of Interest - Declared none.

Finding source and Sponsorship Declared none. 


\section{REFERENCES}

1. Casadevall A, Pirofski L Host-Pathogen Interactions: The Attributes of Virulence. J InfectDis. 2001;184(3):337-344

2. Koo H, Allan RN, Howlin RP,Stoodley P,Hall-Stoodley L Targeting microbial biofilms: current and prospective therapeutic strategies. Nat Rev Microbiol. 2017;15(12):740-755.

3. GabrilskaRA, Rumbaugh KP.Biofilm models of polymicrobial infection. Future Microbiol. 2015;10(12):1997-2015

4. Peterson SN, Snesrud E, Liu J, Ong AC, Kilian M, Schork NJ, etal. The Dental Plaque Microbiome in Health and Disease. Highlander SK, editor.PLOS ONE. 2013:8(3):e58487.

5. van Houte J,Lopman J, Kent R. The Predominant Cultivable Flora of Sound and Carious Human Root Surfaces. J Dent Res. 1994;73(11):1727-34.

6. Ghabraei S, Bolhari B, Sabbagh MM, Afshar MS. Comparison of Antimicrobial Effects of Triple Antibiotic Paste and Calcium Hydroxide Mixed with $2 \%$ Chlorhexidine as Intracanal Medicaments Against Enterococcus faecalis Biofilm. J Dent Tehran Iran. 2018;15(3):151-60.

7. Yadav RK, Tikku AP,Chandra A, Verma P,Bains R, BhootH. A comparative evaluation of the antimicrobial efficacy of calcium hydroxide, chlorhexidine gel, and a curcumin-based formulation against Enterococcus faecalis. Natl J Maxillofac Surg. 2018;9(1):52

8. Athanassiadis B, AbbottP, Walsh L The use of calcium hydroxide, antibiotics and biocides as antimicrobial medicaments in endodontics. AustDent J. 2007:52:S64-82.

9. Ayhan H, Sultan N, Cirak M, Ruhi MZ, Bodur H. Antimicrobial effects of various endodontic irrigants on selected microorganisms. Int Endod J. 1999;32(2):99-102

10. Russell A. Biocide use and antibiotic resistance: the relevance of laboratory findings to clinical and environmental situations. Lancet Infect Dis. 2003;3(12):794-803.

11. Watts A, Paterson RC. The response of the mechanically exposed pulp to prednisolone and triamcinolone acetonide. IntEndod J. 1988;21(1):9-16

12. Neelakantan P,Romero M, Vera J,Daood U, Khan A, Yan A, et al. Biofilms in Endodontics-CurrentStatus and Future Directions. Int J Mol Sci. 2017;18(8):1748.

13. Yoo Y-J, Perinpanayagam H, Oh S, Kim A-R, Han S-H, Kum K-Y.Endodontic biofilms: contemporary and future treatment options. Restor Dent Endod 2019;44(1):e7.

14. Alrahman MSA, Faraj BM, Dizaye KF.Assessment of Nitrofurantoin as an Experimental Intracanal Medicament in Endodontics. BioMed Res Int. 2020;Feb 18:1-13.

15. Sato T,Hoshino E, Uematsu H, Noda T. In vitro antimicrobial susceptibility to combinations of drugs of bacteria from carious and endodontic lesions of human deciduous teeth. Oral Microbiol Immunol. 1993;8(3):172-176.

16. Hoshino E, Kurihara-Ando N, Sato I,Uematsu H, Sato M, Kota K, etal. In-vitro antibacterial susceptibility of bacteria taken from infected root dentine to a mixture of ciprofloxacin, metronidazole and minocycline. Int Endod J. 1996;29(2):125-130.

17. Meropol SB, Chan KA, ChenZ, Finkelstein JA, Hennessy S, Lautenbach E, et al. Adverse events associated with prolonged antibiotic use. Pharmacoepidemio Drug Saf. 2008;17(5):523-532.

18. Kugaji MS, Kumbar VM, Peram MR, Patil S, Bhat KG, Diwan PV. Effect of Resveratrol on biofilm formation and virulence factor gene expression of Porphyromonas gingivalis in periodontal disease. APMIS. 2019;127(4):187-195.
19. Miles AA, Misra SS, Irwin J0. The estimation of the bactericidal power of the blood. J Hyg (Lond). 1938;38(6):732-749.

20. Qaiyumi S. Macro and microdilution methods of antimicrobial susceptibility testing. In: Antimicrobial Susceptibility Testing Protocols. Schwabe R, Steele-Moore L, Goodwil A, editors. United State of America: CRC Press;2007. pp75-79.

21. Clinical and Laboratory Standards Institute. Performance standards for antimicrobial susceptibility testing; nineteenth informational supplement. CLSI document M100-S19, Wayne, PA: Clinical and Laboratory Standards Institute, 2009:29(3)

22. Liljemark WF,Bloomquist C. Human Oral Microbial Ecology and Dental Caries and Periodontal Diseases. Crit Rev Oral Biol Med. 1996;7(2):180-198.

23. Nair PNR, Sjögren U, Krey G, Kahnberg K-E, Sundqvist G. Intraradicular bacteria and fungi in root-filled, asymptomatic human teeth with therapy-resistant periapical lesions: A long-term light and electron microscopic follow-up study. JEndod. 1990;16(12):580-8.

24. Yamane K, Ogawa K, Yoshida M, Hayashi H, Nakamura T, Yamanaka T,etal. Identification and Characterization of Clinically Isolated Biofilm-forming Grampositive Rods from Teeth Associated with Persistent Apical Periodontitis. $J$ Endod. 2009:35(3):347-52

25. Hollenbeck BL, Rice LB. Intrinsic and acquired resistance mechanisms in enterococcus. Virulence. 2012;3(5):421-569.

26. Evans M, Davies JK, Sundqvist G, Figdor D. Mechanisms involved in the resistance of Enterococcus faecalis to calcium hydroxide. Int Endod J. 2002:35(3):221-8.

27. Pereira RS, Rodrigues VAA, Furtado WT, Gueiros S, Pereira GS, Avila-Campos MJ. Microbial analysis of root canal and periradicular lesion associated to teeth with endodontic failure. Anaerobe. 2017:48:12-8.

28. Garcez AS, Ribeiro MS, Tegos GP,Núñez SC, Jorge AOC, Hamblin MR. Antimicrobial photodynamic therapy combined with conventional endodontic treatment to eliminate root canal biofilm infection. Lasers Surg Med. 2007:39(1):59-66.

29. Nomura R, Ogaya Y,Nakano K. Contribution of the Collagen-Binding Proteins of Streptococcus mutans to Bacterial Colonization of Inflamed Dental Pulp. Wen ZT,editor.PLOS ONE. 2016;11(7):e0159613.

30. Peters LB, van Winkelhoff A-J, Buijs JF, Wesselink PR. Effects of instrumentation, irrigation and dressing with calcium hydroxide on infection in pulpless teeth with periapical bone lesions. Int Endod J. 2002;35(1):13-21.

31. Mohammadi Z,AbbottPV. On the local applications of antibiotics and antibiotic-based agents in endodontics and dental traumatology. IntEndod J 2009;42(7):555-67.

32 Ordinola-Zapata R,Bramante CM, Minotti PG, Cavenago BC, Garcia $\mathrm{RB}$, Bernardineli N, etal. Antimicrobial activity of triantibiotic paste, $2 \%$ chlorhexidine gel, and calcium hydroxide on an intraoral-infected dentin biofilm model.JEndod. 2013;39(1):115-8.

33. Lin S, Levin L, Peled M, Weiss El, Fuss Z Reduction of viable bacteria in dentinal tubules treated with clindamycin or tetracycline. Oral Surg Oral Med Oral Pathol Oral Radiol Endodontology.2003;96(6):751-6.

34. Siqueira JF,Uzeda M de. Intracanal medicaments: Evaluation of the antibacterial effects of chlorhexidine, metronidazole, and calcium hydroxide associated with three vehicles. JEndod. 1997;23(3):167-9.

35. Khademi AA, Saleh M, Khabiri M, Jahadi S. Stability of antibacterial activity of Chlorhexidine and Doxycycline in bovine root dentine. JRes Pharm Pract. 2014:3(1):19-22 
36. Behra-Miellet J, Dubreuil L Jumas-BilakE Antianaerobic activity of moxifloxacin compared with that of ofloxacin, ciprofloxacin, clindamycin, metronidazole and $\beta$-lactams. Int J Antimicrob Agents. 2002;20(5):366-74.

37. Löfmark S, Edlund C, Nord CE. Metronidazole Is Still the Drug of Choice for Treatment of Anaerobic Infections. Clin InfectDis. 2010;50(S 1):S16-23.

38. Segura-Egea JJ,Gould K, Sen BH, Jonasson P,Cotti E, Mazzoni A, et al. Antibiotics in Endodontics: a review. Int Endod J. 2017;50(12):1169-84.

39. Torabinejad M, Khademi A, Babagoli J, Cho Y, Johnson W, Bozhilov K, etal. A New Solution for the Removal of the Smear Layer. J Endod. 2003;29(3):170-5.
40. BezerraMM, Brito GAC, Ribeiro RA, Rocha FAC. Low-dose doxycycline prevents inflammatory bone resorption in rats. Braz J Med Biol Res. 2002;35(5):613-6.

41. LeCorn DW, Vertucci FJ, Rojas MF,Progulske-Fox A, Bélanger M. In Vitro Activity of Amoxicillin, Clindamycin, Doxycycline, Metronidazole, and Moxifloxacin Against Oral Actinomyces. JEndod. 2007;33(5):557-60.

42. Chan Y,Chan C-H. Antibiotic resistance of pathogenic bacteria from odontogenic infections in Taiwan. J Microbiol Immunol Infect Wei Mian Yu Gan RanZaZhi. 2003;36(2):105-10.

\section{Prasanna T. Dahake}

(Corresponding address)

Ph. D. Student, Pharmacology and Pedodontics, (Interdisciplinary Sciences)

DMIMS (Deemed to be University), Sawangi (M), Wardha,

Maharashtra, India. Pin code - 442004.

Date submitted: 2020 May 01

E-mail: prasannadahake@gmail.com 